\title{
Spatial characteristics of access of third-country citizens to the Hungarian public health care system
}

\author{
SÁNDOR ILLÉS ${ }^{1}$ and Éva GELLÉR-LUKÁCS²
}

\begin{abstract}
The effect of international migration on public health care system is one of the emerging themes within health and mobility studies. Unfortunately, there is scarce information on health situation of international migrants in Central and Eastern Europe. This research paper tries to contribute filling in this gap with a case study related to Hungary and it deals with the access and participation of third-country nationals to the Hungarian public health care system as patients. The study integrates quantitative and qualitative methodologies coupled with a holistic approach. Macro data of the National Health Insurance Fund was analysed and field works in the National Ambulance Service and at the Semmelweis University (Budapest) were carried out. The volumes and rates of nationals of Ukraine, China, Vietnam, Serbia, former Yugoslavia, Russia and Mongolia are the dominant groups in the provision of acute care, in-patient care, out-patient care, dental care and cash benefits. Acute care is relatively the most populous and medical treatments in capital institutions as opposed to countryside ones. The main spatial factors affecting the provider and supplier side of public health care system in Hungary are identified while concluding that third-country migrants utilize selectively the institutions of the Hungarian public health care system. Conclusions subscribe to the need for future research in this theme in the light of most recent international mobility upheavals.
\end{abstract}

Keywords: international migration, public health care system, third-country citizen, mobility, spatial pattern, Hungary

\section{Introduction}

The national health care system is built up as an elaborated structure. The rules of access and of service provision are complex in Hungary. This inherently compound structure is further supplemented by distinct international rules to third-country nationals. Key stakeholders of the system are the health care providers themselves that are required to put the national, international and supranational legal rules into practise. They are required to solve the financial and administrative tasks and to sort out the concrete cases related to third-country nationals. They have direct contact with the patients, they communicate with the persons concerned and, most importantly, they provide for the appropriate medical care (GELLÉRné LuKÁCS, E. 2012; BELL, D. et al. 2015).

The heterogeneity of third country patients, the frequency of demand of medical services, the type of the treatments within public health care are all fundamental research terrains to be investigated since health is one of the main elements of wellbeing and inequality, too (Thomas, F. and Gideon, J. 2013; JАKAB, Zs. and Tsouros, A.D. 2014). The research aimed at examining the access and participation of third-country nationals in the Hungarian public health care system.

Within the framework of the research carried out between 2006-2010 the following specific questions arose: What is the citizen-

\footnotetext{
${ }^{1}$ Active Society Foundation, H-1094 Budapest, Liliom u. 8. E-mail: dr.illes.sandor@gmail.com

${ }^{2}$ Eötvös Loránd University, Faculty of Law, Postgraduate Institute. H-1051 Budapest, Egyetem tér 1-3.

E-mail: drlukacseva@gmail.com
} 
ship distribution of third-country nationals? What kind of services and medical treatments are frequently used by them? Are the demographic and medical characteristics of foreign patients (sex, age, consumption of medical treatment) similar to that of Hungarian patients? Are there special challenges towards foreign patients for service providers?

\section{International migration context}

In Hungary quantitative and qualitative changes began in 1988 after four decades of a controlled and restrictive migration regime. Due to the political transformation process in Central and Eastern Europe there was also a turn in the types of international migration flows. Hungary got integrated into the European and international migration systems again (То́тн, J. 2012). There was a significant growth of international migration of foreign citizen flows in Hungary which became a receiving and a transit country after a long period of being a sending area. As a result of the continuous inflows and moderate outflows the number of foreign citizens staying in Hungary rose steadily. At the end of 1999 more than 150,000 long-term immigrant were living in Hungary, so their share within the total population rose above 1.5 percent. It is worth mentioning that it was a low proportion in European context (KINCSES, Á. 2015).

An increase of international immigration flow could be measured in the years following Hungary's EU accession ( $11^{\text {st }}$ of May, $2004)$. The number of immigrants exceeded 25,000 per year. The surplus came from other countries of the European Union. However, neighbouring countries played a rather small role in the quantity of immigration (Gellérné LuKács, É. 2011). The attraction of Hungary has been gradually decreased in parallel with Hungary falling into economic crises from the end of 2008. The number of foreign citizens living in Hungary in 2009 was 184,358 persons, so their share within the total population increased above 1.8 percent. 36 percent moved from Romania, at about 10 percent from Ukraine and Serbia. Only 3 percent came from the neighbouring Slovakia. Germans had 9 percent plus other non-German Europeans owned 17 percent. Chinese possessed 6 percent plus other non-Chinese Asians had 7 percent . Citizens of American countries had 2 percent while Africans had 1 percent (GöDRI, I. et al. 2014).

The issues of asylum seekers and refugees are treated differently from the regular international migration. The Office of Immigration and Nationality (OIN) collects and publishes data about them. The legal regulations established three different categories: refugee (menekült in Hungarian) according to Geneva Convention temporary protected asylum seekers (menedékes) and persons granted subsidiary protection (oltalmazott-befogadott). In the middle of the 1990's, with the escalation of the Yugoslav war, ethnic Bosnians, Serbs and Albanians arrived in Hungary and applied for temporary shelter and they obtained asylum-seeker status.

Before the accession of Hungary to the EU the average number of asylum applications was high (5,000 per year). Soon after the accession it diminished to an annual average of 2,000. All in all asylum applicants were 41,000 between 2001 and 2012. More than 75 percent arrived illegally with the help of human traffickers. Many applicants moved forward to the West from the refugee camps even before the Hungarian official decision was passed, because they initially wanted to reach Western Europe. Only a few applicants were granted refugee status (less than $10 \%$ ). For instance, between 2001 and 2012 only 1,616 persons received conventional refugee status in Hungary. Asylum applicants were Afghan, Iraqi and Bangladeshi. Considerable quantitative change has been started from 2013 due to the liberalisation of Hungarian legal rules. It means that asylum applicants who arrive illegally are not arrested during the examination of their application.

During the first half of 201311,741 asylum applicants arrived in Hungary mainly from Kosovo, Pakistan and Afghanistan. The stock 
of recognised applicants was as follows in January 2013 in Hungary: 1,513 persons as refugees, 1,121 temporary protected asylum seekers and persons granted subsidiary protection. New sort of international movement of people of third nationals has been emerging since 2013. The number of quasi-transit tourists-migrants-asylum seekers reached the tens of thousands of people in $2013(18,000)$ and $2014(47,000)$. This value increased to 177,000 people till 15 September 2015 only that year.

Hungary - as member of the European Union and part of the Schengen area - is committed to fulfil all requirements concerning controlling and protecting the external borders of the EU. Hungary is situated on the illegal migration route from the Balkans to Western Europe. As a transit country emphasis needs to be placed on handling the "transit traffic", intensifying border control and maintaining internal security. Hungary's accession to the Schengen area in December 2007 has not affected the illegal migration routes in short-term, it has not changed in any significant way. Main source and transit areas of the continuously increasing illegal migration flows are the Middle East, Asia Minor, Northern Africa and the Balkans.

\section{Legal context}

Hungarian public health care system is horizontally accessible for economically active third-country nationals. Persons in paid employment or self-employed persons who are paying social insurance contributions are entitled to access the public health care system. Two sorts of health related benefits exist in Hungary for third country nationals: health care (in kind) benefits and sickness (cash) benefits (EMN-Hungary 2013).

Additionally, access to health care for those third-country nationals who are not pursuing economic activity is, as a main rule, subject to the registration of habitual residence and possession of the permanent residence permit. Persons who are insured or qualify as insured have access to medical treatment and justify their entitlement with the possession of TAJ (Social Insurance Identification Number). The public health care provider controls the eligibility of the patient via the on-line database, on the basis of the TAJ number.

For refugees and asylum seekers Hungary operates the same system of health care as for nationals (including double or multiple citizens), with no additional requirements and no forms of care excluded. Refugees and asylum seekers do not have to pay premium costs. It is financed from state budget. Higher costs could be in those cases where refugees or asylum seekers turn to private institutions. On the question of the extent of coverage for asylum seekers we stress that they are on equal footing with nationals.

As a main rule, Hungarian health care is free of charge for eligible persons, no extra charges shall be paid by the beneficiary. However, a remarkable exception is dental care, which is mostly a privately run business. It is only free of charge for the age group 0-6 and over 65 . If the third-country national has no entitlement (e.g. the migrant has not lived in Hungary for at least one year or he/ she is undocumented), he/she is required to provide for his/her medical coverage on private basis. Emergency health care, however, is provided by the Hungarian public system without previously controlling the entitlement, and if there is no entitlement, the costs must be reimbursed a posteriori by the international migrant. The same applies to Hungarian nationals in lack of entitlement.

The Hungarian health insurance is based on individual legal relationships. Every insured or entitled person acquires rights on its own. Following from this, health insurance provisions do not acknowledge the secondary rights of family members for accessing healthcare. The legal situation and rights of children and other relatives of the insured person shall be decided individually. The public healthcare system is operated by the National Health Insurance Fund (NHIF), via its central service and with the involvement 
of its regional organs. Regionally the operation is based on the health insurance fund directorates of the capital and county government offices (GELlérné Lukács, É. 2012).

Beyond national and EU law, Hungary has a limited number of bilateral agreements which also give basis for entitlements of thirdcountry nationals. Among the social security agreements these are the agreements with Montenegro and Bosnia-Herzegovina that give entitlement to Hungarian health care benefits. Additionally, foreign citizens coming from the below-enumerated countries are entitled to have access to the undoubtedly necessary in-kind benefits of the Hungarian health care system if their state of health urgently requires: Jordan, Angola, Iraq, Mongolia and Cuba. ${ }^{2}$ For example in the field of healthcare, in the year of 2012 the Hungarian competent institution, NHIF, issued CG 111 forms (for Montenegro) amounting to 954, in relation to Croatia HR111 amounting to 29, HR112 amounting to 14 . No forms were issued in relation to Bosnia-Herzegovina. On the receiving side, in 2012 insured persons of Montenegro applied for 117 medical treatments in Hungary while insured persons of Croatia for 661 cases. From 1 July 2013 Croatia became Member State of the EU; consequently, Regulation (EU) No 883/2004 supersedes the bilateral agreement in this field.

In sum, as a main rule, entitlement is granted on an individual basis for third country nationals, based on national law, EU law and bilateral agreements. Those holding long-term residence permits (both in terms of Directive 2003/109/EC ${ }^{3}$ and as defined by national legislation) and third-country nationals (holding

\footnotetext{
${ }^{2}$ Jordan (incorporated by 15/1981. MT regulation), Kuwait (incorporated by 33/1979. MT regulation), People's Republic of Angola ( incorporated by 17/1984. MT regulation), Iraq (incorporated by 47/1978. MT regulation), Mongolia (incorporated by 29/1974. MT. regulation), People's Democratic Republic of Korea (incorporated by 14/1975. MT regulation), Cuba incorporated by Law-Decree No 16 of 1969).

${ }^{3}$ Council Directive 2003/109/EC of 25 November 2003 concerning the status of third-country nationals who are long-term residents.
}

either long-term residence permits or timebound residence permits) if they are economically active workers or self-employed possess entitlement. If the third-country national has no entitlement (e.g. the migrant has not lived in Hungary for at least one year or s/he is undocumented), s/he is required to provide for his/her medical coverage on private basis. Emergency health care, however, is provided by the Hungarian public system without previously controlling the entitlement, and if there is no entitlement, the costs must be reimbursed by the international migrant.

\section{Methods}

Various data types were collected and combined methodology (Zurc, J. 2013; Morgan, D.L. 2014) were utilised during the research due to the complex interrelationship between international migration and health (GATRELL, A.C. 2011). For the sake of comparability quantitative data from administrative sources were also collected. Additionally, field works were carried out according to the requirements of the holistic approach.

The basic macro data of the project came from the NHIF. The time interval of the data ranged from 2006 to 2010 and related only to the third country nationals who obtained public health care in Hungary. The private health care providers were out of the scope of the NHIF data base. The general characteristics of the data were as follows: full scope and register-based. Firstly, it meant that the inevitable distortions of representatives did not burden the validity of information. Secondly, we wished to create time series in order to discover short, medium and long term trends related to demographic, labour market and legal status. However, relevant economic, social and health features of third country nationals (gender, age, family status, educational attainment) have not been gathered by NHIF, unfortunately. Dual citizens access to health care benefits on the basis of their Hungarian nationality (cp. Serbia, Croatia, Ukraine, USA). Thus, data on third-country health care 
consumers relate to those who do not possess Hungarian nationality (Töттôs, Á. 2013).

Two primary institutions formed the basis of the qualitative data collection. These are the Semmelweis University (Budapest) and the National Ambulance Service. Within the framework of the project 51 in-depth, semi-structured interviews with health care providers (doctors, nurses, administrative officers, managers) were carried out, in order to reveal the opinion of the stakeholders of these two institutions (GYENEY, L. and Kovács, G. 2012; KeresztY, É. 2012).

\section{Research results}

The unique database provided by the NHIF contains information related to third-country nationals possessing TAJ between the years 2006 and 2010. The database consisted of the public health care consumption of thirdcountry nationals staying legally in Hungary. As methodological notes it is put forward that the private health care consumption of third-country nationals was out of the scope of this paper. The analysis was based on data of administrative nature deriving from fullscale register that already had archive data files as well. We distinguished the types of care: emergency health care (acute care), outpatient care, in-patient care, dental care and cash benefits. According to the advantages of the administrative data available the focus will be on citizenship matters in the following sections.

\section{Utilisation of acute care services}

The absolute number of third country nationals who received acute care in Hungary was 11,776 between 2006 and 2010. The distribution of acute care treatment by citizenship mirrored strong concentration by citizenship. 82 percent of the care recipients came from seven countries, namely, Ukraine, China, Vietnam, Serbia, former Yugoslavia, Russia and Mongolia. It is to be traced that the structure of third-country nationals echoes the block of former socialist countries of the past century. It is suggested that, albeit the research aims at describing current trends, it severely faces the heritage of the past, almost 50 years long history.

The nationals of Ukraine had the highest number $(4,810$ persons) within the mass of third-country foreign citizens. Chinese people were situated in the second place with a severely less absolute number $(2,430$ persons). Vietnamese citizens held the third place (1,204 persons). These third-country nationals were followed by the citizens of neighbouring countries like Serbia and former Yugoslavia (370 plus 881 nationals). The third country nationals from Russia had limited absolute number (770 persons). Finally, citizens of Mongolia could be seen with 376 persons.

The full scope register based statistics contain data on the costs of acute care. So it is possible to compute a financial indicator, too. The average price was 34,400 HUF (ca. 110 EUR) per acute care recipient per year (Table 1).

Table 1. Aggregate data on third-country national's medical care recipients in Hungary between 2006 and 2010

\begin{tabular}{|c|c|c|c|c|c|}
\hline $\begin{array}{l}\text { Type of } \\
\text { treatment }\end{array}$ & $\begin{array}{l}\text { Number } \\
\text { of care } \\
\text { recipients }\end{array}$ & $\begin{array}{l}\text { Average cost } \\
\text { per person, } \\
1,000 \text { HUF } \\
\text { per year }\end{array}$ & $\begin{array}{l}\text { Rate of the } 7 \text { most } \\
\text { considerable } \\
\text { nationalities within } \\
\text { third-country care } \\
\text { recipients, } \%\end{array}$ & $\begin{array}{l}\text { Rate of the third-country } \\
\text { care recipients treated in } \\
\text { the } 7 \text { most considerable } \\
\text { receiving counties, } \%\end{array}$ & $\begin{array}{c}\text { Share of } \\
\text { Budapest, } \\
\%\end{array}$ \\
\hline Acute care & 11,776 & 34.4 & 82 & 94 & 61 \\
\hline In-patient care & 9,414 & 34.4 & 94 & 95 & 63 \\
\hline Out-patient care & 72,306 & 3.0 & 79 & 85 & 57 \\
\hline Dental care & 18,123 & 1.1 & 86 & 86 & 55 \\
\hline Cash benefit & 3,961 & 81.6 & 93 & 94 & 66 \\
\hline
\end{tabular}

Source: NHIF data and the authors' own calculations. 


\section{Utilisation of in-patient care services}

Altogether 9,414 third country nationals received in-patient cares. The distribution of in-patient care treatment by citizenship mirrored stronger concentration compared to acute cares. 94 percent of the in-patient care recipients came from the same 7 countries, namely, Ukraine, China, Vietnam, former Yugoslavia, Serbia, Russia and Mongolia.

We received data about sex only in case of in-patient care. It is to be mentioned that Chinese and Vietnamese male had medical problems requiring in-patient care only to a very limited extent. Even urological incidents were negligible.

In case of female, gynaecological medical interventions, prenatal and newborn care were outstandingly dominant. The over representation of these two nations were the highest in the context of immigrant share by citizenship.

The statistics of NHIF contain data on the costs of acute care. The average price was 34,400 HUF per acute care recipient per year (see Table 1).

\section{Utilisation of out-patient care services}

Altogether 72,306 third country nationals got out-patient cares. This was the most numerous group among the types of treatment analysed. But the distribution of out-patient care treatment by citizenship was least concentrated. 79 percent of the out-patient care recipients came from the seven countries under investigation.

The full scope register based statistics contain data on the costs of each type of treatment. The average price of out-patient care was 3,000 HUF (ca. 10 EUR) per out-patient care recipient per year. This was one of the smallest average costs if we compare it with the average acute care and average in-patient care costs (both 34,400 HUF) (see Table 1). We did not discover peculiar cases from a citizenship point of view in the Hungarian counties.

\section{Utilisation of dental care services}

Altogether 18,123 third country nationals experienced dental cares in Hungary between 2006 and 2010. The distribution of dental care treatment by citizenship mirrored medium level concentration. It was an intermediary position between in-patient care $(94 \%)$ and acute care (82\%). 86 percent of the dental care recipients came from seven countries. The nationals of Ukraine had the highest number $(6,617$ persons) within the mass of foreign citizens. Chinese people were in the second place with much less absolute numbers $(3,038$ persons). Vietnamese citizens held the third place (1,718 persons). These nationals were followed by the citizens of former Yugoslavia (1,636 people)

The full scope register based statistics contain data on the costs of dental care. The average price was 1,100 HUF (ca. 3.5 EUR) per dental care recipient per year. This was the smallest average cost (see Table 1). The average value of the indicator seems too small at first sight according to the everyday experiences in Hungary but we did not explore peculiar aggregate dental cases from citizenship point of view through the lens of receiving counties.

\section{Access to cash benefit}

Altogether 3,961 third country nationals got cash benefit in Hungary between 2006 and 2010. This was the least numerous mass among the types of treatment analysed. The distribution of cash benefit gainers by citizenship echoed one of the strongest concentrations. 93 percent of the care recipients came from seven analysed countries, namely, Ukraine (1,317 persons), China (992 persons), Vietnam, (758 persons), former Yugoslavia, Russia, Serbia and Mongolia.

The average amount was 81,600 HUF per cash benefit recipient per year. This was the highest average cost among the types under investigation. We did not explore peculiar cases from citizenship angle in destination counties. 


\section{Discussion}

The potential explanatory factors of the structure of citizenship are according to Figure 1. and relevant literature as follows. The significant weight of Ukrainians among the immigrants in Hungary is a satisfactory statistical determinant about the dominance of Ukrainian citizens in all sorts of cares. However, the deep causes are embedded in ethnic Hungarians living near the Hungarian-Ukrainian border and the discrepancies between the development stage of Ukraine and Hungary including public health care systems (Karácsonyi, D. and Kincses, Á. 2011). Ukrainian sort of explanatory factors do not work among the citizens of China and Vietnam. Their share is higher among all cases than their corresponding values as foreign citizens in Hungary. Their overrepresentation mainly correlates to their economic status. They work as self-employed persons. As an additional determinant we may add to the diaspora lifestyle formulating. It must be mentioned that the overwhelming majority of services for Chinese and Vietnamese was provided in the capital city of Budapest (Egedy, T. and Kovács, Z. 2010).

The share of citizens of former Yugoslavia and one of the successor states of Serbia was low comparing to their weight among thirdcountry foreigners in Hungary. The role of ethnic Hungarian communities and their wealthy economic positions is enormous (KinCSES, Á. and TAKÁCs, Z. 2010).

Contrary to the nationals discussed above Russian and Mongolian people are over represented among all types of care compared to their share among immigrants in Hungary. In the Russian case the value would be closely related to the former medical tourist activity, mainly the cases of acute care. The Mongolian case is completely different from the Russian.

The explanation is hidden in the phenomenon of work driven migration of Mongols. But it is not similar to the Chinese or Vietnamese cases because Mongolians are guest-workers that is not self-employed status (Figure 1).
On the basis of the analysis of in-depth interviews at National Ambulance Service and Semmelweis University Budapest (Greney, L. and Kovács, G. 2012; Kereszty, É. 2012), the following main observations can be discovered from the angle of time-space forces. Three main difficulties can be identified: problems of language, communication and culture; absence of medical history; questions of aftercare.

Language, communication and cultural factors

Except for ethnic Hungarian immigrants difficulties are discovered in different language knowledge between suppliers and providers of health care (Fеiтh, J.H. et al. 2010; EKE, E. et al. 2011). The health workers are usually not been helped by an interpreter and/or cultural mediators in public institutions. We must distinguish for example the Semmelweis University's institutions from regional or local health care centres. Physicians working in clinics spent several years in foreign institutes so they have no communication problems in English and/or German. Although physicians speak quiet good foreign language(s) only few nurses and other healthcare employees have appropriate language skills. Interviewees agreed that it is important to speak at least one foreign language on basic level for health workers in an institution which has a lot of foreign patients everywhere in the country.

Religion is the main factor in the field of cultural differences among third-country nationals. Beyond the religious rules covering clothing, patients cannot pursue their everyday life (habit, rituals). For instance, amongst in-care patients, problems arise concerning one of the basic human needs, the meal.

The question of cultural differences puzzled our interviewees. According to the opinion of fthe irst group the medical staff handle this question with much more professional ethics of practice (according to the international requirements emerging on the culturally competent and diversity sensitive services) than a few decades ago. The second 


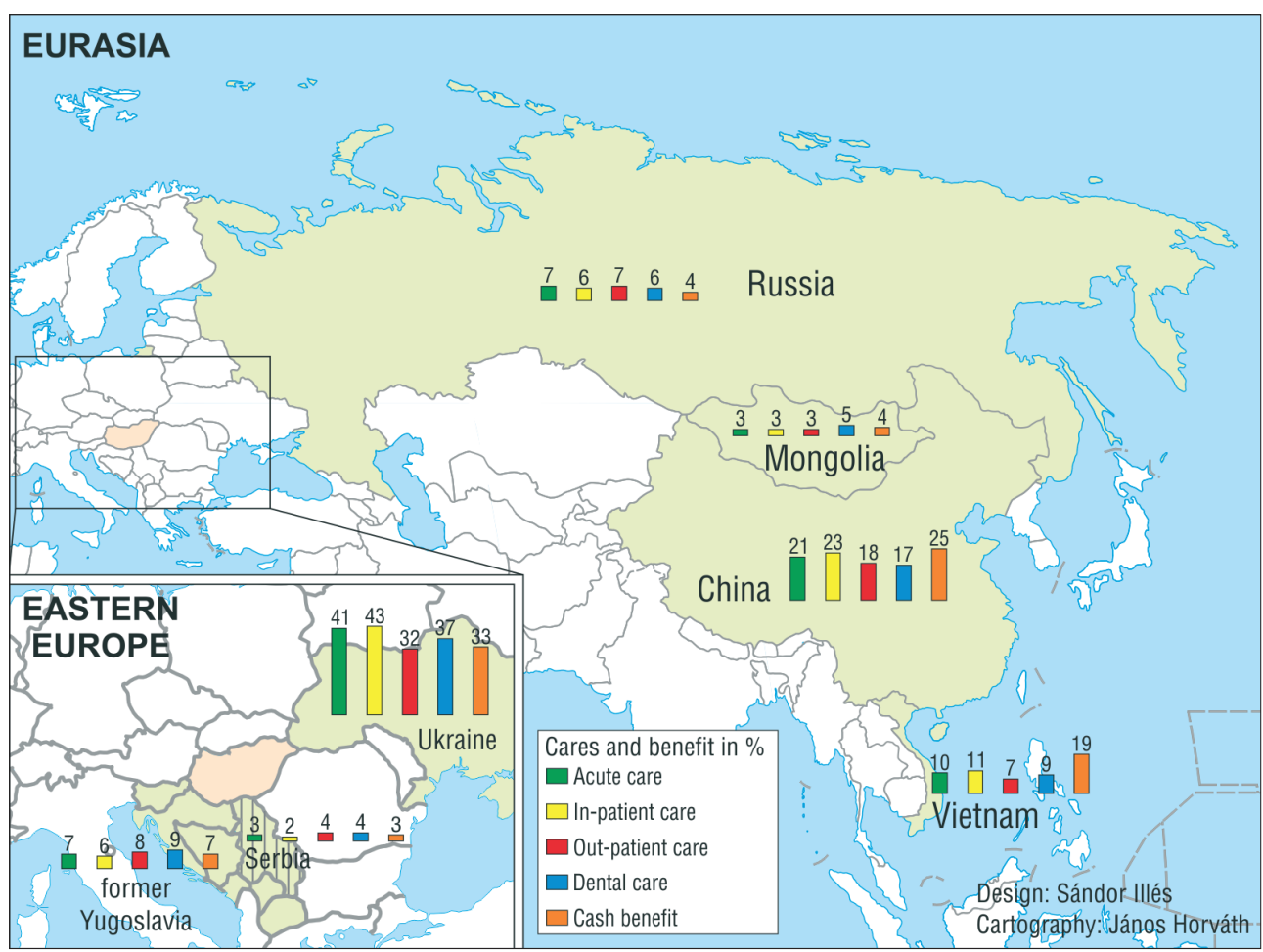

Fig. 1. Regional distribution of types of treatment in Hungary by seven most considerable sending countries, 2006-2010 in percent

group of interviewees found that the problems come from cultural differences which would not be eliminated or solved completely in the healthcare institutions (CRUSH, J. and Tawodzera, G. 2014). Majority of the interviewees agreed that there should be employees knowing or practicing particular cultures in such institutions because a lot of patients having cultural differences.

\section{Role of medical history}

The starting point of each physician-patient relation would be the initiation of the anamnesis (Rezonja, R. et al. 2010) except for the life-threatening situations in acute care. Misunderstanding and lack of medical records are the source of serious problems if foreign patients cannot understand the physician's questions and/or at first stage cannot provide any document on the previous troves (medical findings, records) belong to their own medical history. Moreover, medication of foreign patients should be problematic because drugs used by the patient at home or his/her previous destination are often unknown and/or unavailable in Hungary.

\section{Aftercare}

The patient's aftercare could be problematic in case of emigration, if she/he interrupts the connection with the previous health workers. This problem arises not only in relation to foreigners but also to nationals.

But the rapid development of information, transportation technology and telecommunication, the distinctive function of emigration 
has been eroding. Circulation as the system of multiple and recurring international migration form emerging in the epoch of globalisation (Illés, S. and KINCSES, Á. 2012; MATISCSÁK, A. 2013) may diminish the weight of this problem.

\section{Conclusions}

There is a strong interrelationship among three elements: eligibility to public health care, economic activity and lawful residence in Hungary.

The third-country migrants appear more frequently in the field of emergency care. Ukrainian, Serbian and ex-Yugoslavian nationals appear in relatively huge numbers in Ambulance Services, however, contrary to the previous expectations not in the border counties but rather in the capital city, Budapest. In the case of Chinese nationals obstetrical interventions are dominant. Probably, due to cultural differences the role of traditional Western medicine is less significant within the Chinese community.

A remarkable alternative can be the private (presumably Chinese) health institutions. The relatively big Vietnamese population appears solidly in the out-patient and in-patient care and they hardly use the National Ambulance Service. Russian and Mongolian citizens are over represented among all types of care compared to their weights within third-country nationals in Hungary. In the relatively high Russian values medical tourist activity plays a role.

The explanation of Mongolian values hidden in the phenomenon of work driven migration because of Mongols who are mainly guest-workers in Hungary.

When language, communication and cultural barriers do exist, patients tend not to reach primary health care or preventive medical treatments but immediately the special care. The high territorial concentration of treatments narrow down the effective function of public health care system for thirdcountry nationals.
In the near future we would like to embed our research results in a broader scientific context, but we have found few opportunities to perform international comparisons. The investigation of public and private health care systems utilised by international migrants on macro scale is fundamental worldwide. The emerging databases across countries may be important resources for international comparisons and may allow us to test the robustness of the findings of this Hungarian case study.

Acknowledgement: "Research about access to the health care system" project is co-financed by Tullius Ltd., the European Integration Fund and the Ministry of Home Affairs of Hungary. This paper was financed by Pallas Athéné Geopolitical Foundation, Active Society Foundation and the Local Government of IX. District of Budapest. The authors give special thanks to Prof. Péter Józan for his valuable information and comments.

\section{REFERENCES}

Bell, D., Holliday, R., Ormond, M. and Mainil, T. 2015. Introduction. Transnational healthcare, cross-border perspectives. Social Science \& Medicine 124. 284-289.

Crush, J. and Tawodzera, G. 2014. Medical xenophobia and Zimbabwean migrant access to public health services in South Africa. Journal of Ethnic and Migration Studies 40. 655-670.

Egedy, T. and Kovács, Z. 2010. Governance, strategies and policies in the Budapest Metropolitan Region: how to enhance the city's competitiveness. Amsterdam, University of Amsterdam, $66 \mathrm{p}$.

Eke, E., Girasek, E. and Szocska, M. 2011. From melting pot to laboratory of change in central Europe. Hungary and health workforce migration. In Health Professional Mobility and Health Systems. Evidence from 17 European Countries. Eds.: Wismar, M., Maier, C.B., Glinos, I.A., Dussault, G. and Figueras, J., Copenhagen, WHO - European Observatory on Health Systems and Policies, 365-394.

EMN-Hungary 2013. European Migration Network. Migrant access to social security and healthcare: policies and practice, Hungary. Brussels, European Commission - Ministry of Interior (Hungary).

Feith, J.H., Balázs, P., Garaj, E., Kovácsné-Tóth, Á. and Vingender, I. 2010. Plans for working abroad and career preferences among nursing students in Hungary. New Medicine 14. 22-24. 
Gatrell, A.C. Ed. 2011. Mobilities and Health. Surrey, Ashgate, $229 \mathrm{p}$.

Gellérné LuKács, É. 2011. Free movement of persons - a synthesis. In Central and Eastern European countries after and before the accession. Volume 1. Eds.: Somssich, R. and Szabados, T., Budapest, Department of Private International and European Economic Law, Faculty of Law, ELTE, 51-101.

Gellérné LuKÁcs, É. 2012. Harmadik országbeli állampolgárok a magyar egészségügyben (Thirdcountry nationals in the Hungarian health care system). In Harmadik országbeli állampolgárok hozzáférése az egészségügyi ellátórendszerhez. Ed.: Gellér, B.J. Budapest, Tullius Kiadó, 27-114.

Gödri, I., Soltész, B. and Bodacz-Nagy, B. 2014. Immigration or emigration country? Migration trends and their socio-economic background in Hungary: a longer-term historical perspective. Budapest, Hungarian Demographic Research Institute.

Gyeney, L. and Kovács, G. 2012. Harmadik országbeli állampolgárok részvétele a közfinanszírozott rendszerben - esettanulmányok (Third-country nationals in the public health care sector - case studies). In Harmadik országbeli állampolgárok hozzáférése az egészségügyi ellátórendszerhez. Ed.: Gellér, B.J. Budapest, Tullius Kiadó, 172-261.

Illés, S. and Kincses, Á. 2012. Hungary as a receiving country for circulars. Hungarian Geographical Bulletin 61. (3): 197-218.

JАКАв, Zs. and Tsouros, A.D. 2014. Health 2020 - achieving health and development in today's Europe. Central European Journal of Public Health 22. (2): 133-138.

KarÁCsOnYI, D. and Kincses, Á. 2011. Ukranian citizens in Hungary: national cohesion and economic constraint. In Geography in Visegrad and neighbour countries. Regional Socio-economic processes in Central and Eastern Europe - 20 years in transition and 2 years in global economic crisis. Eds.: Erôss, Á. and KARÁcsonYI, D., Budapest, Geographical Research Institute MTA, 157-169.
Kereszty, É. 2012. A Magyarországon tartózkodó kulföldi személyeknek nyújtott szolgáltatások Szegeden (Health care services for third-country nationals in Szeged). In Harmadik országbeli állampolgárok hozzáférése az egészségügyi ellátórendszerhez. Ed.: Gellér, B.J. Budapest, Tullius Kiadó, 401-435.

KInCSEs, Á. 2015. A nemzetközi migráció Magyarországon és a Kárpát-medence magyar migrációs hálózatai a 21. század elején. (International migration in Hungary and the migration networks of Carpathian Basin in the start of the $21^{\text {st }}$ century). Budapest, Központi Statisztikai Hivatal.

Kincses, Á. and TAKÁcs, Z. 2010. Migration of Serb population before Schengen and the role of neighbouring Hungary. DETUROPE - The Central European Journal of Regional Development and Tourism 2. 56-68.

Matiscsák, A. 2013. Applying the network research matrix methodology to identify and map the international migration of Hungarian nurses. New Medicine 17. 21-27.

Morgan, D.L. 2014. Integrating qualitative and quantitative methods: a pragmatic approach. Los Angeles, CA Sage Publications.

Rezonja, R., Knez, L., Suskovic, S., Kosnik, M. and Mrhar, A. 2010. Comprehensive medication history: the need for the implementation of medication reconciliation processes. Slovenian Journal of Public Health 49. 202-210.

Thomas, F. and Gideon, J. (Eds.) 2013. Migration, Health an Inequality. London, Zed Books.

То́тн, J. 2012. Migration Laws in Hungary. Budapest, Wolters Kluwer Law International.

Zurc, J. 2013. Integrating quantitative and qualitative methodology in health science research: a systematic review. Slovenian Journal of Public Health 52. 221-235. 